\title{
A Review on Risk Factors in the Project of Oil and Gas Industry
}

\author{
Nova Nevila Rodhi ${ }^{1}$, Nadjadji Anwar ${ }^{1}$, and I PutuArtamaWiguna ${ }^{1}$
}

\begin{abstract}
In Each activity in the oil and gas industry there are risks that could hamper the project and also there is a huge risk to the environment, social and economic. Besides oil and gas industry projects also have the potential to be dangerous to life, property and the environment, the hazard can occur if the activity is not controlled and regulated by appropriate. Basically, the disaster is certainly not possible to be planned and can occur at any time. But the circumstances of a disaster can be anticipated, that is the way to plan preventive measures and control.Based on the description above, this paper aims to discuss risk factors and risk assessment techniques that can help sustainable development programs. From the results of this study note that the risk factors of projects in the oil and gas industry is very complex, so a risk analysis must be done from various aspects, namely the project itself, the environment and disaster and should be integrated with aspects of sustainable development. As for the suggested technique is a combination of monte carlo and system dynamics.
\end{abstract}

\section{Keywords—Sustainable Development, Risk Assessment Techniques, Combination Monte Carlo and System Dynamics}

\begin{abstract}
Abstrak-Dalam setiap kegiatan di industri minyak dan gas ada risiko yang dapat menghambat proyek dan juga ada risiko besar terhadap lingkungan, sosial dan ekonomi. Selain proyek industri migas juga berpotensi membahayakan kehidupan, properti dan lingkungan, bahaya bisa terjadi jika aktivitasnya tidak terkontrol dan diatur dengan tepat. Pada dasarnya, bencana ini tentu tidak mungkin direncanakan dan bisa terjadi kapan saja. Namun keadaan bencana dapat diantisipasi, itulah cara untuk merencanakan tindakan pencegahan dan pengendalian. Berdasarkan uraian di atas, makalah ini bertujuan untuk membahas faktor risiko dan teknik penilaian risiko yang dapat membantu program pembangunan berkelanjutan. Dari hasil penelitian ini diketahui bahwa faktor risiko proyek di industri minyak dan gas bumi sangat kompleks sehingga analisis risiko harus dilakukan dari berbagai aspek, yaitu proyek itu sendiri, lingkungan dan bencana dan harus diintegrasikan.
\end{abstract}

\section{Kata Kunci-Sustainable Development, Risk Assessment Techniques, Combination Monte Carlo and System Dynamics}

\section{INTRODUCTION}

$\mathrm{O}^{\mathrm{i}}$ 1 and gas projects at risk due because the large capital investment, the involvement of many parties, the use of complex technology, environmental and social impacts of high [1]. Risk is the possibility of the occurrence of some uncertain events, unexpected and even unwanted which will change the prospects of probability on a given investment [2]. Until social conflicts and casualties due to gas leakage always occurs in the area of oil and gas industry [3].

In general, risk factors, and hazard could occur in the oil and gas industry of the parameters contained in the industrial system [4]. Disasters can happen at any time and certainly can not be prevented. But the impact of a disaster can be minimized with the adoption of a strategy to deal with disasters. One of the causes of the disaster was the result risks are minimized early on. Therefore, in any risk analysis must be integrated with disaster risk analysis.

To achieve the success of the project, all kinds of risks inherent in the project life cycle must be identified so it can be prepared a framework for measuring risks. In addition, it should be noted is related to the reduction of the social, environmental and economic challenge in the construction industry, so the perpetrators of the construction should give priority to the concept of sustainable development in their construction industry [5].

Based on the description above, this paper aims to discuss risk factors and risk assessment techniques that can help sustainable development programs.

\footnotetext{
${ }^{1}$ Nova Nevila Rodhi, Nadjadji Anwar and I Putu Artama Wiguna are
} with Departement of Civil Engineering, Institut Teknologi Sepuluh

\section{LITERATURE REVIEW}

\section{A. Project Risk in Oil and Gas Industry.}

Risk is a condition or situation of internal and external that can influence and change the initial state and the effect on time and cost [6]. Risk is an event or condition that is not certain, that the event could have an impact on project objectives include scope, schedule, cost, and quality [7]. The risk can be defined from various viewpoints. If defined from the viewpoint of the process, the risks are factors that may affect the achievement of objectives, so that the occurrence of unintended consequences, while from the standpoint of risk result is an outcome or outcomes that are not dapatdiprediksikan certain undesirable because it would be counterproductive -productive. Therefore, risk plays an important role in decision-making and can affect the performance of the project [8].

There are two (2) types of project risk, ie the risk of a single project and multi-project risk combinations [9]. In the project there are two (2) sources of risk factors, namely the internal and external [10].

Oil and gas projects at risk due to the large capital investment, the involvement of many parties, the use of complex technology, environmental and social impacts are high [1]. Any activity in the oil and gas industry there are risks that could hamper the project and also there is a huge risk to the environment, social and economic [11][12]. Risk is a condition or situation of internal and external that can influence and change the initial state and the effect on time and cost [6].

Nopember, Surabaya, 60111, Indonesia. E-mail: 


\section{B. Disaster in the Oil and Gas Industry}

The oil and gas project also has the potential oil and gas industry that is dangerous to life, property and the environment, the hazard can occur if the activity is not controlled and regulated appropriately [13]. As well as the emergence of social conflicts and casualties due to gas leakage always occurs in the area of oil and gas insdustri [3]. In the oil and gas projects in addition to their risk there is also a potential hazard into a disaster [4]. Basically disaster is certainly not possible to be planned and can occur at any time. But the circumstances of a disaster can be anticipated by considering the risks and the level of toughness [14].

In the UNDP 2010 stated that disaster risk is the potential loss arising from disasters in a region and a certain period of time which can be death, injury, illness, life is threatened, the loss of a sense of security, displaced, damage to or loss of property, and disruption of community activities caused of the interaction between natural or human activities with vulnerability (Vulnerable Condition).

Hazard is classified into three (3) categories, namely:

1. Natural hazard is the harm caused by factors relating to the climatic and geographical factors

2. Technological hazard is the harm caused by their technological or industrial accidents, or the presence of dangerous procedures, infrastructure failures or other events that may cause loss of life or injury, property damage, social and economic disruption ataudegradasi environment.

3. Environmental degradation is a process of natural resource damage or alter the natural processes of ecosystems to negative caused by human activity and behavior and are sometimes combined with natural disasters.

Disasters can happen at any time and certainly cannot be prevented. But the impact of a disaster can be minimized with the adoption of a strategy to deal with disasters. One of the causes of the disaster was the result risks are minimized early on. Therefore, in any risk analysis must be integrated with disaster risk analysis [15].

\section{Risk Assessment Techniques}

To achieve the success of the project, all kinds of risks inherent in the project life cycle must be identified so it can be prepared a framework for measuring risks. Therefore, required the development of a simple statistical model to quantify the risk, so that it can be applied by the offender construction services effectively [16]. In addition, it should be noted is related to the reduction of the social, environmental and economic challenge in the construction industry, so that the perpetrators of the construction should give priority to the concept of sustainable development in the construction industry they [5]. Sustainable development cannot be achieved if disaster risk reduction are not prioritized into policies, planning and implementation of development, thereby disaster risk reduction must become an integral part of sustainable development. [17].

Sustainable development is a development concept that aims to provide quality of life better for everyone, both now and also utuk generations in the future [18]. Their risk management greatly influence the success of sustainable development [19]. Based on this that risk management needs to be studied. In the PMBOK (Project Management Body of Knowladge) noted that the risk management of the project includes the implementation of risk management planning, identification, analysis, response planning and control and monitoring of the project, and the key to risk management is the identification and assessment of risks [10].

\section{RESULTS AND DISCUSSION}

\section{A. Identification of Risk Factors}

The identification results conducted by researchers earlier mentioned that there are many risk factors that affect to oil and gas projects, either from internal factors and external factors. The risks factors are summarized in table 1 and table 2 below.

TABLE 1.

RISK FACTORS OF OIL AND GAS PROJECT

\begin{tabular}{ll}
\hline \hline \multicolumn{1}{c}{ Risk factors } & \multicolumn{1}{c}{ Reference } \\
\hline Internal & $20 ; 1 ; 21 ; 22$. \\
Design & $20 ; 1 ; 12$. \\
Construction & $20 ; 21 ; 12$. \\
Procurement & $20 ; 1 ; 21 ; 22$. \\
Finance & $20 ; 1 ; 21 ; 23$. \\
Operational & $1 ; 21 ; 24 ; 23$. \\
Contract & $1 ; 21$. \\
Stakeholders & $1 ; 21$. \\
Logistic & $24 ; 4 ; 15 ; 25 ; 23$ \\
Technologi & $24 ; 23$. \\
Accidents & $1 ; 21 ; 24 ; 22$. \\
Distribution and lost employee & $21 ; 12 ; 14 ; 22$. \\
Management & \\
External & $11 ; 20 ; 1 ; 26 ; 12 ; 13 ; 14$. \\
Social & $20 ; 12$. \\
Political & $1 ; 21$. \\
Law & $27 ; 28$ \\
Production Competition & $20 ; 27 ; 28 ; 12 ; 13 ; 14$. \\
Economy & $11 ; 26 ; 20 ; 1 ; 12 ; 13 ; 29 ; 30 ; 14 ; 23$. \\
Environment & 13 \\
Property &
\end{tabular}


TABLE 2.

DISASTER RISK FACTORS OF OIL AND GAS PROJECTS

\begin{tabular}{ll}
\hline \hline \multicolumn{1}{c}{ Risk Factors } & \multicolumn{1}{c}{ Reference } \\
\hline \hline Natural & $31 ; 15 ; 32 ; 33 ; 34 ; 35$. \\
Technological & $24 ; 4 ; 15 ; 25 ; 33 ; 36 ; 23 ; 37 ; 22$. \\
Environmental & $31 ; 15 ; 32 ; 33 ; 34 ; 35$. \\
\hline
\end{tabular}

\section{B. Identification of Risk Assessment Techniques}

The importance of integrating the various aspects of the application of risk management to encourage researchers to look into the matter with several different methods. The methods used in a wide variety of research itegrasi these risks include SPSS can use to measure project risks can and should be integrated with the environmental risk assessment [1]. Potential risks can be determined by Multi Attribute Group Decision Making (MAGDM) and analyzed by GTOPSIS [21]. The hybrid motode Economic Input-Output Life Cycle Assessment (EIOLCA) can to help decision makers make better decisions about the construction industry, adding the quality of the environment and sustainable development [38]. Assessment of environmental impacts caused by the construction industry can also be done by way of risk assessment [26].

Integration projects and the environment is not enough if without regard to the sustainability of both. Therefore, the use of algorithms and methods for the measurement of Microsoft Project integration and sustainable environmental projects, this method can be used to develop a prototype of sustainable development planning system to reduce the negative impact of the construction industry on the environment [39]. The SWOT method can to plan resources in achieving sustainable planning [40]. For ongoing emphasis on management to do with the method Multilevel and Multi-Scale [41]. Multidimensional scaling and hierarchical cluster analysis is considered feasible used to integrate and evaluate social considerations in construction projects [42]. The model SFM (sustainable facilities management) to mengidetifikasi aspects of sustainability [25]. and analysis can be used method RBCA (Risk-based corrective action) [43].

As already mentioned above, that the concept of sustainable development cannot be separated from the discussion penanggunlangan disaster, the results of studies suggest that to evaluate the risks, dangers, and accidents can be done by methods Tree Analysis [30]. Meanwhile, to measure disaster risk, the method Community Action Plan for Seismic Safety (CAPSS) can to obtain a sustainable strategy that disaster [44]. Environmental Impact Assessment is also recommended for use in understanding the preparedness, response and recovery of disasters caused by natural or technological [15]. The methods CFPR (Consistent Fuzzy Preference Relations) to identify and assess the level of hazard in a project [45]. While natural hazard analysis can be done using metrics [46].

However, of the various results of various researches, the overall integration is not visible and yet to be developed. This is due to the integration of insightful analyzes on the concept of sustainable development required a technique that can measure the variables that are very complex. ISO 31010 in the year 2009 on Risk Management mentioned that the system is too complex to the effects of uncertainty when using the technique of analysis can be evaluated by mempertimbangakan random variables. Monte Carlo method can be helpful when the parameters of the model used in the form of statistical distribution that aims to predict the statistical behavior of a system output. Monte Carlo draw a set of parameters of the distribution of possible values, and use of existing parameters to execute a dynamic model [47]. But the Monte Carlo method does not produce a settlement, but it generates a way to assess the optimal answers including answers and not all situations can be assessed, unless the situation which contains uncertainties, which required the study of other methods that can solve a problem in a variety of situations.

Dynamical systems (System Dynamics) is a proven effective method for modeling and analyzing complex variable, dynamic and non-linear interaction [48]. This method can provide a reference for decision makers if it wants to improve the sustainability of the project. This study provides an alternative approach to improve sustainability and make a useful contribution to promoting the principles of sustainable development [49]. The dynamical system can analyze the feedback mechanism [50]. But in this case the required data is very complex, so the simulation can be performed with optimal [51]. The results of the study which combines Monte Carlo and Dynamic Systems demonstrate how a holistic perspective to understand and capture the complex network of multiple nodes are interconnected [52].

\section{CONCLUSION}

From the results of this study note that the risk factors of projects in the oil and gas industry is very complex, so a risk analysis must be done from various aspects, namely the project itself, the environment and disaster and should be integrated with aspects of sustainable development. As for the suggested technique is a combination of montecarlo and system dynamics.

\section{REFERENCES}

[1] N. Van Thuyet, "Risk management in oil and gas construction projects in Vietnam," Int. J. Energy Sect. Manag., vol. 1, no. 2, pp. 175-194, 2007.

[2] A. Enhassi, "Risk Management in Building Projects: Owners' Perspective," Islam. Univ. J. (Series Nat. Stud. Eng., pp. 95-123, 2008.

[3] D. Ambarsari, "Minyak Kami Tanggung Jawab Kami Transparansi Migas untuk Pembangunan Berkelanjutan: Belajar Dari Blora dan Bojonegoro,” 2009.

[4] Bolado, "Best practices and methodological guidelines for conducting gas risk assessments," 2012.

[5] H. Zabihi, "Sustainability in Building and Construction: Revising Definitions and Concepts," Int. J. Emerg. Sci., vol. 2, no. 4, pp. 570 578, 2012.

[6] R. Choudhry and K. Iqbal, "Identification of risk management systems in construction industry in Pakistan," J.Manage. Eng., pp 42-49.

[7] Anonimus, A Guide To The Project Management Body Of Knowledge (PMBOK GUIDE), Fourth Edi. American National Standard, 2008.

[8] I. P. A. Wiguna and S. Scott, "Nature Of The Critical Risk Factors 
Affecting Project Performance In Indonesian Building Contracts," in 21st Annual ARCOM Conference, 2005, pp. 225-235.

[9] H. Corvellec, "The practice of risk management: Silence is not absence," Risk Manag., vol. 11, pp. 285-304, 2009.

[10] M. El-Sayegh Sameh and H. Mansour Mahmoud, "Risk Assessment and Allocation in Highway Construction Projects in the UAE," $J$. Manag. Eng., 2015.

[11]F. A. Ogwu, "Challenges of Oil and Gas Pipeline Network and the role of Physical Planners in Nigeria," FORUM Ejournal, vol. 10, pp. 41-51, 2011.

[12] N. N. Rodhi, "Kajian Risiko Penggunaan Sumber Daya Air Berbasis Paradigma Bottom-up Approach (Studi kasus wilayah eksplorasi Banyu Urip Bojonegoro),"Universitas Diponegoro, 2012.

[13]O.-W. Achaw and Boateng, "Safety practices in the oil and gas industries in Ghana," Int. J. Dev. Sustain., vol. 1, no. 2, pp. 456465, 2012.

[14]H. Voogd, "Disaster Prevention in Urban Environments," Eur. J. Spat. Dev., pp. 1-20, 2004.

[15] R. A., F. B. Olorunfemi, G. P. Awotayo, A. M. Tunde, and B. A Usm, "Disaster Risk Management and Social Impact Assessment: Understanding Preparedness, Response and Recovery in Community Projects," in Environmental Change and Sustainability, InTech, 2013

[16]Renuka, "A Review on Critical Risk Factors in the Life Cycle of Contruction Projects," J. Civ. Eng. Res., vol. 4, no. 2A, pp. 31-36, 2014.

[17]M. Tingay, O. Heidbach, R. Davies, and R. Swarbrick, "The Lusi Mud Eruption of East Java," Curtin, 2009.

[18]M. Abduh, "Konstuksi Ramping Untuk Mencapai Konstruksi yang berkelanjutan," in Seminar Nasional Sustainability Dalam Bidang Material, Rekayasa, dan Konstruksi Beton, 2007, pp. 213 - 225.

[19]E. Osipova and P. E. Eriksson, "Balancing control and flexibility in joint risk management: Lessons learned from two construction projects," Int. J. Proj. Manag., vol. 31, no. 3, pp. 391-399, 2013.

[20] Mojtahedi, et al. "Risk Identification and Analysis Concurrently: Group Decision Making Approach". Proceedings of the IEEE ICMIT. 2008

[21] Namian, et al (2016). "Improving Hazard-Recognition Performance and Safety Training Outcomes: Integrating Strategies for Training Transfer". J. Constr. Eng. Manage., 04016048. ASCE, ISSN 07339364. 04016048-1 - 04016048-11.

[22] Campidelli M, et al (2015). "Blast Design-Basis Threat Uncertainty and Its Effects on Probabilistic Risk Assessment". ASCE-ASME J Risk Uncertainty Eng. Syst., Part A: Civ. Eng. DOI: 10.1061/AJRUA6.0000823. (C) 2015 American Society of Civil Engineers. Pp. 04015012-1 - 04015012-15

[23]Zhendong, Wu et al. "Risk Assessment of Oil and Gas Drilling Engineering Cooperation Project Based on Fuzzy Comprehensive Evaluation". Proceedings of the 7th International Conference on Innovation \& Management. 2011. Pp.1662 - 1667.

[24]Collins, Dave danJunghans, Antje. (2015). "Sustainable facilities management and green leasing: The company strategic approach". Procedia Economics and Finance 21 ( 2015) 128 - 136 www.sciencedirect.com

[25]Zolfagharian, et al. (2012). "Environmental Impacts Assessment on Construction Sites".Construction Research Congress 2012 C ASCE 2012.Hal. 1750 - 1759.

[26] Razaque, Abdul, et al. (2012). "Fostering Project Scheduling and Controlling Risk Management". International Journal of Busines and Social Science Vol. 3 No. 14 [Special Issue - July 2012]. Hal 118 - 127. www.ijbssnet.com

[27] Mursitama, Tirta N andYudono, Maisa, (2010). StrategiTiga Naga EkonomiPolitikIndustriMinyakCina di Indonesia”. ISBN.978-60295766-9-6. KepikUngu.Depok. Indonesia.

[28]Bonstrom, Holly. Corotis, Ross B. dan Porter, Keith. (2012). "Overcoming Public and Political Challenges for Natural Hazard Risk Investment Decisions". Journal of Integrated Disaster Risk Management.IDRiM(2012)1(1) ISSN: 2185-8322. Hal. 1 - 23.

[29]El Attar, Ibrahim. danKhattab, Wael. (2013). "Risks Assessment of Oil and Gas Transportation in the Suez Canal Sector".The international maritime transport $\&$ logistics conference (marlog 2). Sustainable development of suez canal region 17 - 19 MARCH 2013. Pp. 1- 11

[30]Kemp, René , (2005). "Governance for sustainable development: moving from theory to practice". Int. J. Sustainable Development, Vol. 8, Nos. 1/2, 2005. Pp.12 - 30

[31] Osman, Wan et al. (2012). "Adoption Level of Sustainable Construction Practices: A Study on Malaysia's Construction Stakeholders". Journal of Southeast Asian Research.Vol. 2012
(2012), Article ID 270273, 6 pages. DOI: $10.5171 / 2012.270273$. http://www.ibimapublishing.com/journals/JSAR/jsar.html

[32] Rosentröm, Ulla. (2006). "Exploring the Policy Use of Sustainable Development Indicators: Interviews with Finnish Politicians". The Journal of Transdisciplinary Environmental Studies, ISSN 1602 2297. Vol 5. No. 1-2. 2006. Pp. 1- 13. http://www.journal-tes.dk/.

[33] Kemp, René , (2005). "Governance for sustainable development: moving from theory to practice”. Int. J. Sustainable Development, Vol. 8, Nos. 1/2, 2005. Pp.12 - 30

[34]Kates, Robert W et al, (2005). "WHAT IS SUSTAINABLE DEVELOPMENT? Goals, Indicators, Values, and Practice". Issue of Environment: Science and Policy for Sustainable Development, Volume 47, Number 3, pages 8-21. (C) Robert W. Kates, Thomas M. Parris, and Anthony A. Leiserowitz, 2005. For more information about Environment, see http://www.heldref.org/env.php

[35]Zou, P., Chen, Y., and Chan, T. (2010). "Understanding and improving your risk management capability: Assessment model for construction organizations." J. Constr. Eng. Manage., 10.1061/(ASCE)CO.1943-7862.0000175, 854-863.

[36] Galbusera, Luca;et al. (2016). "Inoperability Input-Output Modeling: Inventory Optimization and Resilience Estimation during Critical Events". ASCE-ASME J. Risk Uncertainty Eng. Syst., Part A: Civ. Eng., B4016001. B4016001-1 - B4016001-10

[37] Sharrard, Aurora ,et al. (2008). "Estimating Construction Project Environmental Effects Using an Input-Output-Based Hybrid LifeCycle Assessment Model". Journal Of Infrastructure Systems (C) ASCE / DECEMBER 2008. Hal. 327 - 336.

[38] Irizarry, Javier, et al (2012). "The Development Of A SustainableConstruction Planning System". Journal of Information Technology in Construction - ISSN 1874-4753.ITcon Vol. 17 (2012).Hal.162 178

[39] Hashemi, H.et al. (2013).“Compromise ranking approach with bootstrap confidence intervals for risk assessment in port management projects." J. Manage. Eng., 10.1061/ (ASCE)ME.1943-5479.0000167, 334-344.

[40] Gargiulo, C. (2013). "A Multilevel and Multi-Scale Method To Optimise The Sustainable Construction Works". Sustainable Building Conference 2013.Coventry University.Hal. 322- 331

[41] Vasquez, Rodolfo Valdes and Klotz, Leidy. (2013). "Social Sustainability Considerations during Planning and Design: Framework of Processes for Construction Projects". Journal Of Construction Engineering And Management (C) ASCE / January 2013. American Society of Civil Engineers. DOI: 10.1061/(ASCE)CO.1943-7862.0000566. hal. 80 - 89.

[42] Yang Z.H; et al. (2015). "Development of the Risk Assessment and Management Strategies for TPH Contaminated Sites Using TPH Fraction Methods". J. Hazard. Toxic Radioact.Waste, D4015003. C ASCE, ISSN 2153-5493/D4015003(10). D4015003-1 - D401500310.

[43] Bonstrom, Holly et al. (2012). "Overcoming Public and Political Challenges for Natural Hazard Risk Investment Decisions".Journal of Integrated Disaster Risk Management.IDRiM(2012)1(1) ISSN: 2185-8322. Hal. $1-23$.

[44]Patel K.A; Kikani K.D and Jha K.N. (2016). "Hazard Assessment Using Consistent Fuzzy Preference Relations Approach”. J. Constr. Eng. Manage., 04016067. (C) ASCE, ISSN 0733-9364. 04016067-1 - 04016067-10

[45] Gilbert, Stanley andAyyub, M. (2016). "Models for the Economics of Resilience". ASCE-ASME J. Risk Uncertainty Eng. Syst., Part A: Civ. Eng., 04016003. 04016003-1 - 04016003-11.

[46] Houghton, Jameset al, (2014). "A Survey of Methods for Data Inclusion in System Dynamics Models: Methods, Tools and Applications". Working Paper CISL\# 2014-03.Massachusetts Institute of Technology. Cambridge, MA 02142.

[47]Goh, Yang Miang and Love, Peter ED. (2012). "Methodological application of system dynamics for evaluating traffic safety policy".Safety $\quad$ Science $\quad 50 \quad$ (2012).Hal.15941605.www.elsevier.com/locate/ssci

[48]Dudley, Richard G, (2007). "Payments, penalties, payouts, and environmental ethics: a system dynamics examination". Sustainability: Science, Practice, \& Policy. Volume $3 \bullet$ Issue 2 Fall 2007. ISSN: 1548-7733 Pp. 24 - 35. http://ejournal.nbii.org.

[49] Shin, Mingyu. Lee, Hyun-Soo. Park, Moonseo. Moon, Myunggidan Han, Sangwon.(2013). "A system dynamics approach for modeling construction workers'safety attitudes and behaviors".Accident Analysis and Prevention 68 (2014). www.elsevier.com/locate/aap. Hal.95-105.

[50]Zhang, YB. Chen, YQ and Zhu, XY. (2012). "Risk Management for Construction Projects with Colored Petri Nets: an Agent-Based 
Modeling Framework". Proceedings of the 2012 IEEE IEEM.Hal. $2008-2012$

[51] Ghadge, Abhijeet et al. "A systems approach for modelling supply chain risks". Supply Chain Management: An International Journal, Vol.18 No.5, 2013. Pp 523-538. 